American Journal of Environmental Sciences 6 (1): 11-19, 2010

ISSN 1553-345X

(C) 2010 Science Publications

\title{
Impacts of Trade and Environment on Sustainable Development
}

\author{
Rabiul Islam, Chamhuri Siwar and Shaharuddin Mohamad Ismail \\ Institute for Environment and Development (LESTARI), University Kebangsaan Malaysia, \\ 43600 UKM Bangi, Darul Ehsan, Selangor, Malaysia
}

\begin{abstract}
Problem statement: This study investigated the issues of trade and environment on sustainable development. It has reviewed the existing literatures on trade and environment and conceptualized the economic, environmental and social effects of sustainable development. The review has six parts. Approach: Firstly, we discussed the market access, barriers to trade and impediments. Secondly, we state the trade liberalization, timber trade and environment. Results: Thirdly, we analyzed the agreements on tropical timber. Fourthly, we explained illegal logging, deforestation and pollution on trade and environment. Fifthly, we study sustainable forest management. Conclusion: Finally, we related the sustainable development on tropical timber trade. The purpose of this study was to highlight and clarify the impacts of trade and environment on sustainable development.
\end{abstract}

Key words: Market access, trade agreement, illegal logging, sustainable forest management, sustainable development

\section{INTRODUCTION}

Trade and environment are an important role for sustainable development. They affect directly and indirectly on sustainable development. Siwar et al. (2008) state a framework for analyzing the links between poverty, environment and sustainable development of developing countries. They also analyze that the issues of economic growth, poverty and sustainable development are well known in the development debate during the past couple of decades.

The maintenance of the sustainability of environmental functions constitutes a community interest, so that it demands responsibility, openness and a role for members of the community, which can be channeled by people individually, environmental organizations, such as non-government organizations, traditional community groups and others, for maintaining and increasing environmental supportive and carrying capacity which becomes a mainstay of sustainable development. Development which incorporates the environment, including natural resources, is a medium for attaining sustainable development which is a guarantee of prosperity and quality of life of present and future generations (Jafar et al., 2008; Asia-Pacific Economic Cooperation, 1998)

Al-Amin et al. (2008) presents the globalization process such as trade liberalization in the Malaysian economy and Malaysian environmental policies, environmental motivations toward sustainability from 1947-2005 and extensively study various issues of Malaysia such as transition of Malaysian economy of pre and post industrial stage; trade liberalization policies that enhanced the trade liberalization, air emissions and Malaysian environmental policies of sustainability for 2020 .

Economists generally argue that the internalization of environmental externalities of economic activity is a necessary step towards sustainable development. Sustainable development continues to be emphasized that the well-being of the present generation is not met at the expense of future generations. Economic, social and environmental aspects will be increasingly integrated into the development process. Environmental considerations are integrated into sectoral policies in order to ensure sustainable economic and social development. Besides acquiring the requisite technical capacity, the government implements more efficient and cost-effective command and control measures to reduce and minimize pollution as well as to improve the quality of life (Malaysian Development Programme, 2006).

Al-Amin et al. (2007) analyzes the contribution of services sector as well as pollution implication of services sector for the production of different industries in the Malaysian economy. They also reveal the

Corresponding Author: Rabiul Islam, Institute for Environment and Development (LESTARI),

University Kebangsaan Malaysia, 43600 UKM Bangi, Darul Ehsan, Selangor, Malaysia

Tel: +603-89214161 Fax: +60389255104 
contribution of services sector in the Malaysian economy and the quantitative assessment of selected air emissions of services sector in the economy.

International environmental agreements are aimed at addressing problems of global proportions. Malaysia has ratified several international agreements including the framework convention on climate change, the convention on biological diversity, the Basel convention on the transboundary movement of toxic and hazardous wastes and their disposal, Convention on International Trade in Endangered Species (CITES), wetlands of international importance (RAMSAR), the convention on desertification and the montreal protocol for the protection of the ozone layer to phase out CFCs (Khalid and Braden, 1993).

Environmental laws and regulations can be divided into two broad categories. The first represent policies that are domestically initiated and aimed at environmental protection and conservation. These measures generally affect exports indirectly. The second generally consist of environment measures that are the outcomes of international agreement, conventions or arrangements (Asafu-Adjaye et al. 1997).

Siwar et al. (2008) states that trade can affect the environment in two ways: Firstly, trade and trade liberalization encourage industrialization and manufacturing of production, leading to increased pollution. Secondly, industrialization and manufacturing of production lead to increased overuses of environmental resources and environmental degradation.

The aim of this study is to obtain the development of market access, trade barriers, trade liberalization, environmental degradation and pollution, sustainable forest management and sustainable development.

\section{MATERIALS AND METHODS}

Data attainment: The study is conducted in University Kebangsaan Malaysia, Bangi since July, 2008 to November, 2009. The data for analysis is perceived from secondary sources in Malaysia. The significant manipulations are market access, trade liberalization, agreements on tropical timber and sustainable development. The corresponding outcomes are demonstrated from the analysis of collected information.

Market access, barriers to trade and impediments: Market access: Market access is an important role in the tropical timber trade to international tropical timber markets. It can be described as the conditions under which producers are able to offer products for sale. These conditions are the consequences of decisions by importers and exporters and also a consequence of the inherent characteristics of the sector and products. Trade, environment, development, welfare and social are the complex issues of market access of tropical timber trade. The issues related to market access, tend to be both complicated and highly political. The market access of tropical timber needs a comprehensive approach to international markets. Market access is influenced by importing-exporting countries and international trade regime. The influences are less clearly defined due to numerous linkages between forests, the environment and the sustainable development (Rytkonen, 2003).

Some studies examine the downturn in the market access of international tropical timber market. The importance of their studies shows the Organization's work on trade and environment, the issue of substitution by non-wood materials and the importance of life-cycle comparisons. The item as a key action area has been identified by the Intergovernmental Panel on Forests (IPF, 1997).

Barriers to trade: All the various environmental impacts of trade and economic policies on natural resources are difficult to assess, but evidence indicates the presence of both negative and positive impacts. Most of the tariffs cover to effectively very low levels and non-tariff measures and other impediments and market failures state the movement toward optimal trading patterns. Importer countries have in the past reduced tariff barriers to trade to economize on their tropical wood raw material. This has improved their local industrial cost competitiveness both against substitute materials (such as boreal and temperate hardwoods and softwoods and other materials) and in comparison with tropical producer countries. Producer countries have introduced export bans, restrictions, quotas and taxes to increase rent capture from tropical forest resource and to create incentives for domestic further processing. Lately, many producer country policies have gradual deregulation of the trade. Lowering the producer country barriers and impediments causes necessary structural adjustment measures by the industry of the producer country. Market access barriers and impediments may affect the prevailing market for tropical timber trade.

Export restrictions are commonly used to encourage and promote greater domestic processing by protecting local industry from import competition, enabling the local industry to obtain $\operatorname{logs}$ at cheaper prices the most developing countries and in some 
developed countries. Since export bans are technically illegal under of GATT, many countries (such as Indonesia and Malaysia) are now turning to other measures, ranging from export taxes to permits and licenses, in place of direct quantitative controls. In recent years, there has been shifting towards encouragement of value added timber products such as sawnwood and even more recently towards forest sustainability issues, where the intent is to reduce overall pressure on the resource (Bourke, 1999).

Export restrictions include total bans, export quotas, or selective bans based on species; direct charges such as export taxes or export levies; indirect quantitative restrictions due to controls on harvest levels and administrative controls such as permits and licenses. The export taxes for processed products, sawnwood, veneer and plywood are usually negligible or small. Forest-based industries promotion has become more important with an increasing need for economic development. From the point of view of effectiveness and cost, the export bans have been criticized. They have caused substitution of wood for other factors of production from an economic production function point of view. Some studies have indicated that the restrictions have been effective in contributing to the industrial development goal, but at a substantial financial cost (Barbier et al., 1995).

Tariff and non-tariff barriers focus on trade in forest-based products. Even though the former have been significantly reduced as the result of the Uruguay Round, they still represent a restriction; particularly in the context of tariff escalation (higher tariffs are applied to value-added products than raw material or intermediate products). A variety of Non-Tariff Barriers (NTBs) or Non-Tariff Measures (NTMs) may be even more important and their importance appears to be increasing (Bourke, 1995).

Lower tariff barriers for developing countries, in the form of GSPs which are discretionary, tend to retain high tariffs for these finished products. It is not clear whether they are enough to exclude some developing countries from exporting such products to developed countries since there may be other factors which may influence that outcome (Bourke and Leitch, 2000).

Impediments: Trade impediments are usually motivated by environmental concerns. They are currently having some impact on trade levels and patterns of timber products. In the timber sector, they are intended at encouraging sustainable forest management. These impediments include bans and boycotts on the use of timber from forests which are not sustainably managed. Many of these bans are linked to the certification of timber products, whereby consumers could be assured that the wood in the product they are buying comes from a sustainably managed source. Finally, the Convention on International Trade in Endangered Species of Wild Fauna and Flora (CITES) uses degrees of trade restrictions to regulate trade in endangered species (Rytkonen, 2003).

Trade liberalization, timber trade and environment: Rytkonen (2003) has stated that trade liberalization has led to a rapid growth of world trade and the environmental impacts of this growth. By creating market opportunities for such products, liberalized trade can add value to forest products that are sustainably produced. However, the increased competition can also create pressure to exploit the resource base more intensively. The international trade rules have been extensively reviewed in the literature in respect of the appropriateness of the disciplines and how they should be best applied in order to avoid unnecessary adverse effects.

Murad and Mazumder (2009) state the relationship between trade liberalization, economic growth and the environment in Asia-Pacific. They also reveal that trade liberalization can have both positive and negative impacts on the environment evidence from Malaysia and that the economic integration constrains national environmental policymaking. On the one hand, increased trade can lead to expansion of production, employment and consumption, which is associated with a rise in living standards and a reduction of poverty. Trade liberalization can promote the efficient allocation of resources worldwide and therefore reduce pressure caused by over-exploitation of global natural resources.

To decompose the potential effect of trade liberalization on the environment in terms of these three affects the composition, scale and technique effects (Grossman and Krueger, 1995; Nordstrom and Vaughan, 1999). They produce more of under free trade that the composition effect arises from country differences in the products. These differences are the country differences in comparative advantage. The country in the environmentally damaging goods (the South) will increase and non-environmentally damaging goods (the North) will increase production of that goods under free trade. Hence, environmental degradation will increase in the South and decrease in the North. The scale effect arises from increased income, production, consumption and hence environmental degradation. Techniques of production are always harmful to the environment which this negative effect is the technique effect. Trade liberalization on the environment depends on the relative strength of the composition, scale and technique effects. 
Agreements on tropical timber:

International trade agreements: International trade agreements are the essential to ensure proper functioning of free trade, while taking into account the protection of the environment. There are a lot of agreements on tropical timber trade. World Trade Organization (WTO) legislation is the main part of international trade agreements which is based on the General Agreements on Tariffs and Trade (GATT). The WTO agreement has specific implications for the conservation and sustainable forest management: Sanitary and Phyto-Sanitary measures (SPS); Technical Barriers to Trade (TBT); Trade Related Investment Methods (TRIM); Trade-Related Intellectual Property Rights (TRIPs) (Rytkonen, 2003).

International trade rules under the GATT/WTO agreements have been recognized for the need of environmental protection. The WTO Committee on Trade and Environment (CTE) has reviewed environmental issues related to products and their Production and Processing Methods (PPMs) but no significant decisions have been made due to slow progress in this area. The WTO Committee on Trade and Environment (CTE) has recognized the environmental benefits arising from the removal of trade restrictions and distortions in the forest area (Page, 1997; WTO, 2007).

Multilateral environmental agreements: Multilateral Environmental Agreements (MEAs) are the essential to ensure proper functioning of free trade, while taking into account the protection of the environment and legally binding international agreements with a global scope. There are a lot of environmental agreements on tropical timber trade. From the point of view of forestry, the Convention on Biological Diversity (CBD) is one of the most important of the MEAs. MEAs have addressed that the Convention on Biological Diversity (CBD), United Nations Framework Convention on Climate Change (UNFCCC) and United Nations Convention to Combat Desertification (UNCCD) are he most important from the forestry point of view. Multilateral environmental agreements have become of a growing concern with WTO and Non-Governmental Organizations (NGOs) which leading towards a higher coherence of the two large bodies of legislation. Multilateral environmental agreements are international agreements between countries generally aimed at increased protection of the world's natural resources or the promotion of environmental quality. The growing global economy is placing an increasing strain upon global ecosystems while putting them at risk of extinction. As regards, it needs to be recognized that the volume of trade has not shown a growing trend timber from natural tropical forests (Rytkonen, 2003).

Simula (1999) has stated that CITES listing effective measures are needed both in exporting and importing countries. Trade measures as CITES listings should be limited to achieve the objective from the trade point of view. On the other hand, CITES trade restrictions should be made and implemented effectively so that the survival of a species, which is endangered by commercial trade, is indeed ensured by the measures taken.

Page (1997) has stated that most of the environmental effects are indirect in causing changes in levels and patterns of production and consumption while recognizing the potential benefits of trade to the environment. Complementarily can be observed in the WTO and CBD rules can be identified in the area of forest biodiversity (Simula, 1999). The United Nations Framework Convention on Climate Change (UNFCCC) addresses the issues related to climatic influences, including the interface with forest ecosystems.

\section{Illegal logging, deforestation and pollution on trade and environment: \\ Illegal logging: Brack (2007) states that illegal logging} takes place when timber is harvested bought or sold in violation of national laws. He also presents the extent of illegal logging in some countries is so large and law enforcement is so poor. Illegal timber logging not only undermines conservation but also results in reduced profitability of legal trade, loss of foreign revenue and currency exchange, uncollected forest related taxes and depleted forest resources and services.

Buongiorno et al. (2008) describe the long-term effects of eliminating illegal logging on the world forest industries, trade and inventory. They also tell that illegal timber logging and its associated international trade is a major problem for environmental, economic and social reasons. Illegal timber logging hampers important environmental services (Bala et al., 2007; Kinnaird et al., 2003) and it may be a less direct cause of deforestation than land conversion for agriculture raises over exploitation and poor forest management. In terms of economics, Collier et al. (2002) estimates that illegal logging reduces government revenues about \$US5 billion by a year.

Contreras-Hermosillo (2001) presents six categories of illegal activities in the forestry sector. The six categories of illegal activities are illegal occupation of forestlands; illegal logging; arson; illegal timber trade and transport and timber smuggling; transfer pricing and other illegal accounting practices and illegal forest processing. Thomas et al. (2000) state that illegal 
logging put at risk the livelihoods of the poor and directly threaten ecosystems and biodiversity in protected areas and parks across the world. Poor governance and weak law and order are likely to contribute to accelerated deforestation and forest degradation.

Deforestation: Deforestation can be defined as the conservation of forest to another land use or the long term reduction of the tree canopy cover below the minimum $10 \%$ threshold (Food and Agriculture Organization, 2007). Deforestation can be caused by several human activities. It can be caused by migration of farmers from one area to another resulting in the cutting of forest due to the infertility of their previous land. Deforestation can lead to soil erosion or impoverishment where soils tend to be thin and nutrient poor. Without deforestation, forests can grow and withdraw substantial amounts of carbon, accumulating it in trees and soil (Houghton, 2005).

Allen and Barnes (1985) state deforestation can be as the transformation of primary closed forest to any other formation, as the loss of any kind of closed forest, or, as the loss of forestland. They describe that there are many causes of deforestation in developing countries such as Malaysia. Climate, agriculture, logging, fuel, burning and grazing and forest management are the major causes of deforestation. Agricultural expansion increase in deforestation due to land conversion but, income, population growth/density, logging prices/returns/production, agricultural yields and prices/returns, roads/building and scale and institutional factors influence on deforestation (Barbier, 2001).

Sierra (2001) examined the relationship between timber trade and tropical deforestation and forest degradation and the implications for forest conservation policy and planning. Barbier et al. (1995) also studied the linkages between the timber trade and tropical deforestation. They showed that the direct impact of forest activities on deforestation appears to be less than $10 \%$ of total deforestation as compared to agriculture. They explore the relative merits of the different policy interventions in term of deforestation.

Pollution: Pollution has both direct and indirect influences on environment. Industrial pollution affects economic growth in developing countries but, industrial practices produce adverse environmental pollution as the consequences through the disposal of hazardous wastes. Income distribution can affect pollution levels and trade plays a role in the generation of most pollution. He has also showed the economic for income environment is to identify the consumption or household production responsible for some environmental impact and relate to income at the household level.

Iwami (2006) states the globalization and pollution industries in East Asia on trade and environment. East Asian trade affects the production of pollution industries and thereby influences environmental degradations in the region. Pollution industries are using paper and products, industrial chemicals and other chemicals, petroleum refineries, miscellaneous petroleum and coal products.

Grossman and Krueger (1995) examined the relationship between levels of economic development and variety of local pollutants. They also examined sulfur dioxide emissions, smoke, lead, cadmium, arsenic and mercury in water. They estimate the relationship between these pollutants and income. They used a reduced form cubic equation regressing different measures of environmental pollution on per capita gross domestic product. Cole et al. (1997) examined sulfur dioxide, carbon monoxide and nitrogen dioxide.

\section{RESULTS}

Sustainable forest management: Sustainable Forest Management (SFM) is the process of managing forest land to achieve one or more clearly specified objectives of management without undue reduction of its inherent values and future productivity or undesirable effects on the economic, social and environment (ITTO, 1992) and integrates and balances social, economic, ecological, cultural and spiritual needs to present and future generations (United Nations Environment Promramme, 1992). There are three pillars of SFM include the Fig. 1.

Economic: The capacity of the forests to attract investment and support economically viable forest uses in the present and the future is undiminished. The forest is not used beyond its long -term capacity for production of wood and non-wood forest products.

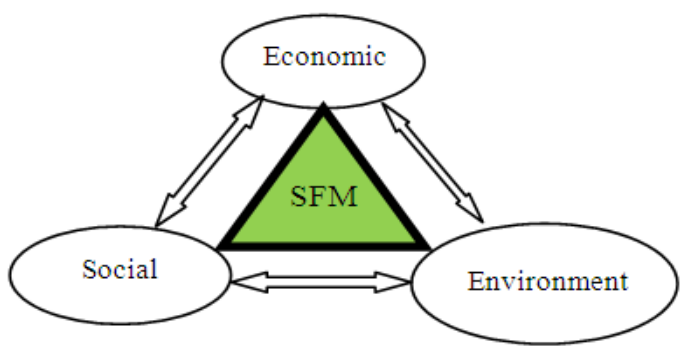

Fig. 1: Pillars of Sustainable Forest Management 


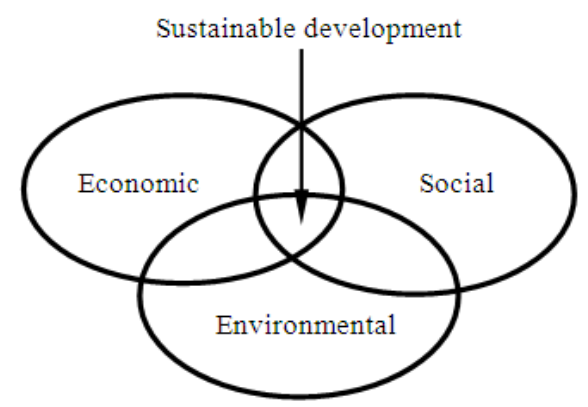

Fig. 2: Sustainable development; Source: World Commission on Environment and Development (1987)

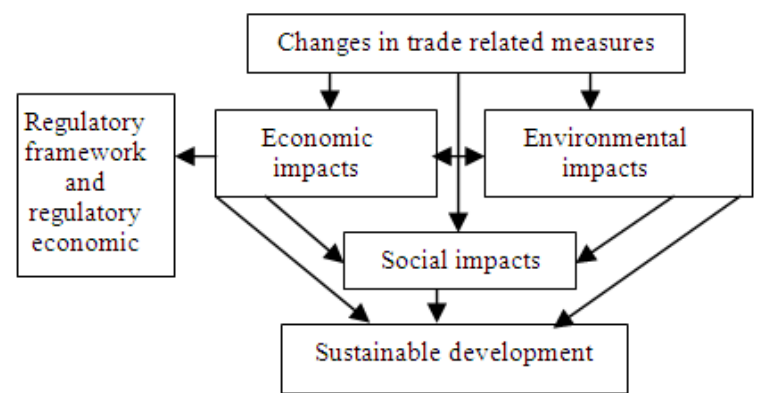

Fig. 3: Impact types of trade liberalization on sustainable development; Source: (Kirkpatrick et al., 2004)

Social: There are a variety of pillars include social such as:

- The rights of indigenous peoples and local communities are respected and protected

- Forest workers are healthy, safe and their rights are protected (e.g., freedom of association, right to bargain, child labor, forced labor, equal remuneration and non-discrimination)

- Local communities, including indigenous peoples, benefit economically from forest management and

- Sites of religious, spiritual, archaeological, historic as well as of aesthetic and recreational value are preserved

Environmental: Forest use protects biodiversity (ecosystems, species, genes and ecological processes) and the capacity to maintain ecosystem processes and services such as watershed protection, pollination, protection against mudslides, aesthetic beauty, carbon storage, etc.

Sustainable development: At present and in future, sustainability is related to the economic, social and environmental systems that make up the community provide a healthy, productive and meaningful life for all community residents (Fig. 2).

The path to sustainable is a threefold process. Sustainable development has three aspects: economic, social and environmental, which are linked together and have overlapping within themselves. So, the three parts and their links are to understanding sustainable development, because sustainable development is about more than quality of life and achieving balance among the social, economic and environmental price of a community.

The analytical framework, which has been used in interpreting the impacts on sustainable development, is shown in the Fig. 3.

\section{DISCUSSION}

Trade rules may influence on the components of sustainable development, such that the effects of liberalization are felt primarily through the extent to which it accelerates or decelerates these other processes. The direction and significance of impacts depends on the nature of the policy and regulatory frameworks are under-developed and well-developed capacity for policy analysis and implementation.

Sustainable forest management implies the sustainable utilization of forest resources for the benefit of communities and states. The concept not only aims to maintain the value of forest resources, it also has a huge potential for creating employment, income and wealth for the populations and states concerned. The sustainable forest management programme seeks to improve the management of natural tropical forests by increasing the adoption of sustainable forest management practices by forest managers from industries to communities. Good forest management can both reduce the negative impacts of timber harvesting on other forest resources and services and increase yields of desired products and services from a given area of forest.

The concept of sustainable development has a fundamental nature and serves as the basis for other new and innovative concepts and principles arising within environmental conventions. Sustainable development is development that lasts for long time. The Brundtland Commission (WCED, 1987) correctly defined sustainable development as, "meeting the needs of the present generation without compromising the ability of the future generations to meet their needs".

The economic pillar is a suitable mix of wood products and non-wood products (plants and animals), that does not diminish the productive capacity of the 
forest. Social pillars include respect for labor and indigenous rights, the health and safety of forest workers, sharing of economic benefits and protection of sites of spiritual or historic value. Environmental pillars can include soil protection, biodiversity, maintenance of air and water quality and aesthetics. The appropriate balance of these pillars will vary among regions and contexts.

Kirkpatrick et al. (2004) explain that trade measures have direct and indirect impacts on sustainable development. Economic, environmental and social impacts are the dimensions of sustainable development:

- Economic impacts: Changes in per capita incomes, net capital formation and employment

- Environmental impacts: Changes in air, water and land quality, in biological abundance and diversity and in other environmental resource stocks

- Social impacts: Impacts on poverty and other measures of inequality; effects on levels of health and education; changes in the culture and cohesion of community life

\section{CONCLUSION}

The literature about the impact of trade and environment on sustainable development has been reviewed. The links of indicators to policy processes, though a relatively new concern for sustainable development, has long been recognized mainly by scholars working on social indicators as a key factor in ensuring effective use. Environmental protection is the concern of all people, including those from developing economies. Developing economies suspect that measures taken by developed economies to link environment with trade might simply be disguised trade barriers. This can be seen from the actions and measures taken by the developing economies to protect the environment and to engage in sustainable development programs. It is argued here that environmental measures should be confined to environmental protection alone and not linked with trade sanctions. Environmental degradation and carelessness in developing economies are mainly due to ignorance and to backwardness in environment technology. Industrialization and economic growth have both positive and negative effects on the environment. Malaysia's economic development has brought large improvements in those environmental problems that are primarily related to poverty and to a low level of economic development. Sustainable development not only yields benefits for the environment, but also it signifies poverty alleviation and giving developing countries a chance to work their way out of poverty and produce jobs, economic growth and better quality of life for employees.

\section{ACKNOWLEDGEMENT}

Financial assistance provided by the Research University Grant (GUP) UKM-GUP-ASPL-07-06-011, Institute for Environment and Development, University Kebangsaan Malaysia is gratefully acknowledged.

\section{REFERENCES}

Al-Amin, A.Q., C. Siwar, A.H. Jafar, M.N.H. Mazumder and E. Hossian, 2007. The services sector's contribution as well as pollution implication in the Malaysian economy: An input-output approach. Proceeding of the SSRN Working Paper Series 1017181, Sept. 25-25, World Bank and Oxford University Press, New York, USA., pp: 1-1. http://papers.ssrn.com/sol3/papers.cfm?abstract_id $=1017181$

Al-Amin, C. Siwar, A. Hamid and N. Huda, 2008. Globalization and environmental degradation: Bangladeshi thinking as a developing nation by 2015. Int. Rev. Bus. Res. Paper, 4: 381-395. http://www.bizresearchpapers.com/30-AlAmin.pdf

Allen, J.C. and D.F. Barnes, 1985. The causes of deforestation in developing countries. Annals of the Assoc. Am. Geograp., 75: 163-184.

Asia-Pacific Economic Cooperation, (APEC), 1998. Trade and Environment. Proceeding of the Workshop, Beijing, China, ISBN: 981-04-1096-4, APEC\# 98-EC-04.4.

Asafu-Adjaye, J., A. Mawuli and R. Kameata, 1997. Integrating Environmental Considerations into Economic Decision-Making Processes: The mineral sector in Papua New Guinea. http://www.unescap.org/drpad/publication/integra/ volume3/png/3pg005.htm

Bala, G., K. Caldeira, M. Wickett, T.J. Phillips and D.B. Lobell et al., 2007. Combined climate and carbon cycle effects of large scale deforestation. http://www.pnas.org_cgi_doi_10.1073_pnas.06089 98104

Barbier, E.B., N. Bockstael, J.C. Burgess and I. Strand, 1995. The linkage between the trade and tropical deforestation. Indonesia. World Econ., 18: 411-442.

Barbier, E.B., 2001. The economics of tropical deforestation and land use: An introduction to the special issue. Land Econ., 77: 155-171. 
Am. J. Environ. Sci., 6 (1): 11-19, 2010

Bourke, I.J., 1995. International trade in forest products and the environment. http://www.fao.org/DOCREP/V7850E/V7850e03.htm

Bourke, I.J., 1999. Trade instruments and their impacts on sustainable forestry development.

Bourke, I.J. and J. Leitch, 2000. Trade restrictions and their impact on international trade in forest products. FAO, Rome. http://www.fao.org/waicent/faoinfo/forestry/FOP/F OPH/bkleich/B98-1.htm

Brack, D., 2007. Action against illegal logging: Interaction with international trade agreements. Proceeding of the Chatham House Workshop on Forest Governance and Trade: Exploring Options, Chatham House, Jan. 24-24, London, UK., pp: 12. http://www.illegal-

logging.info/item_single.php?it_id=454\&it=document

Buongiorno, J., R. Li, J.A. Turner, S. Zhu and J. Prestemon, 2008. Long-term effects of eliminating illegal logging on the world forest industries, trade and inventory. For. Policy Econ., 10:480-490.

Cole, M.A., A.J. Rayner and J.M. Bates, 1997. The environmental Kuznets curve: An empirical analysis. Environ. Dev. Econ., 2: 401-416.

Collier, P., D. Dollar and World Bank, 2002. Globalization, Growth and Poverty. Building an Inclusive World, World Bank Publications, ISBN: 10: 082135048X, pp: 174.

Contreras-Hermosilla, A., 2001. Illegal forest activities in the Asia pacific rim. Markets for Forest Conservation Brief, Washington DC. http://www.foresttrends.org/resources/pdf/pri_illegallogging2.pdf

Food and Agriculture Organization (FAO), 2007. FAOSTAT. Statistical database of the Food and Agriculture Organization of the United Nations, Available at: http://faostat.fao.org/

Grossman, G. M. and A.B. Krueger, 1995. Economic growth and the environment. Q. J. Econ., 110: 353-377.

Houghton, R.A., 2005. Aboveground forest biomass and the global carbon balance. Global Change Biol., 11: 945-958.

IPF, 1997. Report of the ad hoc intergovernmental panel on forests on its fourth session. E/CN. 17/1997/12. http://daccess-ddsny.un.org/doc/UNDOC/GEN/N97/069/11/PDF/N9 706911.pdf?OpenElement

ITTO, 1992. Guidelines for the sustainable management of tropical forests. Yokohama.

Iwami, T., 2006. Globalization and pollution industries in East Asia.

http://www.e.utokyo.ac.jp/cirje/research/dp/2006/2 006cf394.pdf
Jafar, A.H., A.Q. Al-Amin and C. Siwar, 2008. Environmental impact of alternative fuel mix in electricity generation in Malaysia. Renew. Energy, 33: 2229-2235. DOI: 10.1016/j.renene.2007.12.014

Khalid, A.R. and J.B. Braden, 1993. Welfare effects of environmental regulation in an open economy: The case of Malaysian palm oil. J. Agric. Econ., 44: 25-37.

Kinnaird, M.F., E.W. Sanderson, T.G. O'Brien, H.T. Wibisono and G. Woolmer, 2003. Deforestation trends in a tropical landscape and implications for endangered large mammals. Conserv. Biol., 17: 245-257.

Kirkpatrick, C., C. George and S.S. Scrieciu, 2004. The implications of trade and investment liberalization for sustainable development. Impact Assessment Research Centre, Institute for Development Policy and Management, University of Manchester. http://ideas.repec.org/p/ags/idpmia/30576.html

Malaysian Development Programme, (MDP), 2006. building a civilization to elevate the nation's dignity. Ninth Malaysia Plan (2006-2010). Government Printers, Kuala Lumpur. http://www.parlimen.gov.my/news/engucapan_rmk9.pdf

Murad, M.W. and M.N.H. Mazumder, 2009. Trade and environment: Review of relationship and implication of environmental kuznets curve hypothesis for Malaysia. J. Soc. Sci., 19: 83-90.

Nordstrom, H. and S. Vaughan, 1999. Trade and Environment. Special Studies No. 4, World Trade Organization, Geneva.

Page, S., 1997. Environment benefits from removing trade restrictions and distortions: Background for WTO negotiations. http://www.odi.org.uk/resources/download/1658.p df

Rytkonen, A., 2003. Market access of tropical timber. Report to the ITTO, Helsinki, Finland.

Sierra, R., 2001. The role of domestic timber markets in tropical deforestation and forest degradation in Ecuador: Implications for conservation planning and policy. Ecol. Econ., 36: 327-340.

Simula, M., 1999. Convention on Biological Diversity and the International Trade Regime: The Case of Forests. The World Conservation Union (IUCN), Gland, Switzerland and Cambridge, UK.

Siwar, C., Al-Amin and N. Huda, 2008. Globalization, Poverty Inequality and Sustainable Livelihood Diversification in Third World Countries: An Assessment. In: Linking Environment and Rural Poverty: Governance and Sustainable Development Policies, Siwar, C. et al. (Ed.). Institute for Environment and Development (LESTARI), UKM, Malaysia, ISBN: 9789675227059, pp: 95-106. 
Thomas, E., T. Gapotchenko, J.C. Varekamp, E.L. Mecray and M.R. Buchholtz ten Brink, 2000. Benthic foraminifera and environmental changes in Long Island Sound. J. Coastal Res., 16: 641-655. http://www.jstor.org/pss/4300076

United Nations Environment Promramme, (UNEP) 1992. Rio declaration on environment and development. Proceeding of the United Nations Conference on Environment and Development, June 3-14, United Nations Environment Promramme, Rio de Janeiro, pp: 1-1. http://www.unep.org/Documents.Multilingual/Defa ult.asp?DocumentID=78\&ArticleID=1163
World Commission on Environment and Development (WCED), 1987. Brundtland Report: Our common future. Oxford: Oxford University Press. http://sustainablecities.dk/en/actions/a-paradigmin-progress/brundtland-report-our-common-future WTO, 2007. Annual report. WTO Publications, World Trade Organization,

Geneva. http://www.wto.org/english/res_e/booksp_e/anrep_ e/anrep07_e.pdf 